\title{
Religious Local Wisdom For Strengthening Social Harmony: Study in Banyumas Indonesia and New Delhi India
}

\author{
$1^{\text {st }}$ Sadari $^{1}, 2^{\text {nd }}$ Rabiatul Adawiyah ${ }^{2}, 3^{\text {rd }}$ Suwito $^{3}, 4^{\text {th }}$ Salman Faris ${ }^{4}$ \\ \{arifahmikhan@gmail.com¹,wiyahdpr@gmail.com², suwitons@iainpurwokerto.ac.id ${ }^{3}$, \\ stai_azziyadah@yahoo.com ${ }^{4}$ \} \\ Institut Agama Islam Shalahuddin Al-Ayyubi (INISA) Tambun-Bekasi, Indonesia ${ }^{31}$ \\ Universitas Muhammadiyah Jakarta (UMJ), Indonesia ${ }^{32}$ \\ Institut Agama Islam Negeri (IAIN) Purwokerto, Indonesia ${ }^{3}$ \\ Sekolah Tinggi Agama Islam Azziyadah (STAIZA) Jakarta, Indonesia ${ }^{34}$
}

\begin{abstract}
This research aims to explore and analyze religious local wisdom for strengthening social harmony. We will prove the thesis that local wisdom was excavated from religious values has strong power for social harmony, especially majority and minority relation. In Java, Indonesia, in the early Islam, Sunan Kudus tried to understand social context. So, he didn't fight frontally. He used religious local wisdom to respect Hindu as a majority by prohibiting his congregation to slaughter cow and its beef. He applied sad aldariah, a concept in Islam as a risk management. This concept is still valid until now. He built mosque (masjid) by adopting Hindu architecture. This is a cultural and social language. In Banyumas, Jawa, Indonesia, there is the concept of cablaka. It's talking for what it is. Bawor (name of puppet) is an icon of cablaka. The genealogy of cablaka can be traced from Islamic values. Cablaka is a communication model in Region in Jawa, especially in Banyumas. Researchers collect data with the interview, observation, and documentation. Then, we analyze data by Huberman's model (reduction, displaying, conclusion). We choose Banyumas and Kudus as a research location for Indonesia New Delhi for India. The finding of the research is showing that any characteristics religious local wisdom that effective to build social harmony. First, it that improve to make more social interdependent. Second, It produces to make more and deep understand about live. Cablaka in Banyumas and Darma Samanvaya in New Delhi have two characteristics.
\end{abstract}

Keywords: Religious; Local Wisdom; Minority; Majority; Islam

\section{Introduction}

Globally, the social conflict has been seen in any areas (Tcach, 2012). Arab spring in the Middle East, social conflict in central Africa, religious conflict in South Asia, silent conflict in China, race conflict in America and Europe are proving that social conflicts often were driven by differences (Lopera Becerra, 2012). Any differences, like ideology, race, geography, political view become one cause of the conflict (Boris \& Samuel, 2014).

The effect of the social conflict become the cause of social regression. Any refugees fleed to avoid conflict and lived in shelter tents (Spiegel \& Nankoe, 2002). United Nations High Commissioner for Refugees (UNHCR) reported on June 24, 2014, that there were 50 million refugees in the world cause of any conflicts (Sundquist, Hagströmer, Johansson, \& Sundquist, 2010). The refugee data is used in this year in level $150 \%$ than before. BBC cited the Internal Displacement Monitoring Centre (IDMC) in Geneva, Swiss, it reported that some of the refugees are from Asia and the crisis in Africa. ${ }^{1}$

There are any problems in shelter refuge, including education for children, health, clean water and sanitation, and others. Any children lost their education. It means there's lost a generation. The effect of these problems is impoverishment society and decline of the nation (Sundquist et al., 2010).

\footnotetext{
${ }^{1} \mathrm{http}: / /$ internasional.kompas.com, accessed by 10 April 2014.
} 
Good experiences in some Islamic Boarding Schools (Pesantren) in Java (Indonesia) and other places in the world, and New Delhi (India). In Pesantren an-Najah Purwokerto Central Java has tried to use local wisdom as an approach and solution to solve the social crises. The office of Forum Komunikasi Umat Beragama (FKUB) Purwokerto, Followers Religion Communication Forum held in this Pesantren. The leader of FKUB as well as the Kyai of this Pesantren. In their activities, Pesantren taught Islam as a source of peace. Quran and Hadits as main of sources of Islam have the concern to build social harmony and peace. Pesantren an-Najah and FKUB role as an agent of conflict resolution. Any tensions cause sed by religions and social conflicts often have been discussed and solved in this Pesantren. Javanese local wisdom "Guyub Rukun" become an important concept in an-Najah and FKUB in Purwokerto. An-Najah and FKUB tried to elaborate and apply this concept gradually, bit a little bit (Roqib, 2005). ${ }^{2}$

This research also will be done in Jawaharlal Nehru University in New Delhi India. It was chosen because of any uniqueness characteristics in this university. JNU is a university under India law. The goals of the education in this university is to build a peace and social harmony. Its curriculum was developed by the concept of human spirit. The curriculum-based diversity of humanity was implemented by a teaching-learning process in class. Lecturers with their students explore good universal characters like mutual help, love, honest, hospitable and other. Academician can celebrate their holiday and do the ritual of religion in this campus. The campus is for all human being. So, the Moslem student can pray, fasting, and any activities related by religions and believes. This university has some centers, was known Training Center for Character Building based Humanity. At least, there are 32 centers around countries in the world to promote and campaign the

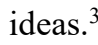

Local wisdom is the potential to reduce and solve the conflict. Because it related to the community's ability to understand the surrounding condition and the environment, which then is adapted to the existing situation. Local wisdom contributes to the way of living, knowledge and life strategies in the form of actions done by the local community to respond to various problems and meet their needs in life. Each community has its own outlook about a conflict that it is facing. The outlook is very dependent on the general conceptual framework, or a culture that surround it. Different outlook or perspective which causes differences can lead to a conflict between a community and another, which may trigger the myth of conflict. Every society has its own perspective of conflict, the myth of conflict, which differs from each other (Alfitri \& Hambali, 2013).

\section{Coindentia Oppsitorum and Social Harmony}

Coincident Oppositorum or unity of opposites (al-jam 'u bain al-'addâd) is a concept that promoted by Greek philosopher scholastic, Heraclitus (535-475 SM) (Parry, 2014). It's a Greek term, that means unity of opposites or unity in diversity.

It's a platonic term that related to mathematics Germany philosopher Nicholas De Docta Ignorantia (in 1440). Mircea Eliade, used this term in his essay about ritual and mythology. Besides that, Carl Jung, Henry Corbin, and Gershom Scholem also used this term for explaining revelation and unity and something that was believed before.

Unity of opposites is the core of concept in dialectic, in mysticism, philosophy, and sciences. This concept can be defined as a situation or identity existed in anything. Whatever any existing depend on co-existent. It's cause of different. On the existent must be different so we can recognize them. If diversity is balanced its result is static, but if imbalance its result is more dominant.

Any article was written by scholars about social harmony and to build peace, Hamid in his article, "Christian-Muslim Relation in Ghana: A Model for World Dialogue and Peace" in Ilorin Journal of Religious Studies said intensive dialogue interfaith can reduce any tension in ChristianMuslim Relation. Both of followers understood to each other. The important key to build peace is communication and intensive dialogue (Fallis, 2013).

Green in her article, "Multiculturalism, Europhilia and Harmonization: Harmony and Disharmony? in Utrech Law Review Journal show that harmony and disharmony in social life are

\footnotetext{
${ }^{2}$ Moh Roqib. (2005). Hamoni dalam Budaya Jawa (Jogjakarta: Pustaka Pelajar), page. 13-23. Interview with Roqib, Kyai of Pesantren an-Najah, April 12, 2015.

${ }^{3}$ Interview with Dardak on April 12, 2015.
} 
choices. In a multicultural society, harmonization is needed as a "capital" for a human being. But, in many cases, conflict is dominant appearance (Sefton-Green, 2010).

Alfitri and Hambali in their article "Integration of National Character Education and Social Conflict Resolution through Traditional Culture: A Case Study in South Sumatra Indonesia", Asian Social Science, has explored about the role of social wisdom. They showed that local wisdom is potential to reduce and solve the conflict. Because it related to the community's ability to understand the surrounding condition and the environment, which then is adapted to the existing situation (Alfitri \& Hambali, 2013).

In 1996 the United Nations published An Agenda for Peace, which argued for proactive peacemaking and humanitarian intervention (Malan, 1997). It outlined suggestions for responding effectively to threats to international peace and security in the post-Cold War era. In particular, four major areas of activity were identified, namely: preventive diplomacy, peacemaking, peacekeeping and post-conflict to build peace. Preventive diplomacy is 'action to prevent disputes from arising between parties, to prevent existing disputes from escalating into conflict and to limit the spread of the latter when they occur' (Malan, 1997). Peacemaking is 'action to bring hostile parties to agreement, essentially through such peaceful means as those foreseen in Chapter VI of the Charter of the United Nations.' Peacekeeping is the deployment of a United Nations presence with the consent of the parties concerned, and with restraint on the use of force except in selfdefence.

Social harmony and Peace building refers to efforts in the medium to long-term process of rebuilding war-affected communities. This includes the process of rebuilding the political, security, social and economic dimensions of a society emerging from a conflict. It also includes addressing the root causes of the conflict and promoting social and economic justice as well as putting in place political structures of governance and the rule of law which will consolidate to build peace, reconciliation, and development. On Lyn Graybill, It is evident therefore that there are numerous challenges to promoting peace in the worlds like Africa (Graybill, 1998). What do we mean when we refer to building peace? We need to consider that, broadly defined, there are two ways to understand the nature of peace and social harmony. For most analysts, there is a distinction between a condition of negative peace and a condition of positive peace (Reychler, Luc., Paffenholz, 2001). Negative peace is the condition that most people refer to when they are discussing issues to do with peace and conflict: it is the condition in which peace is based on the absence of violence. We need to work more towards the notion of positive peace: which means a peace that promotes reconciliation and coexistence on the basis of human rights, social, economic and political justice. In this context, therefore, when we talk about to build peace we are referring to the process whereby the goal is to strengthen the capacity of societies to promote a positive peace. Within most to build peace and development actors and agencies, there is increasingly a focus on the importance of promoting positive peace and social harmony.

An integral part of the process of achieving positive peace is the need to promote social harmony. In an important sense, peace is not just the absence of violence, but the presence of social harmony. Achieving social harmony means that members of the society once again begin to recognize each other as fellow human beings and begin to share a concern in the common welfare and wellbeing of each other. Social harmony makes sense because only by ensuring the security, safety, and wellbeing of other people can we hope to secure our own security, safety, and well-being. To emphasize the need to foster social harmony is to recognize the interconnectedness of each human being. Later on, this paper will argue that only through the promotion of Pan-world social harmony can world countries achieve development (Tim Murithi, 1999).

Colonialism did not only destroy the basis upon which world countries could define themselves but where it could, it also co-opted the indigenous structures and mechanisms of governance and dispute resolution to serve the interests of the colonial administration. Indigenous traditions with regard to governing and resolving disputes in world societies were therefore corrupted by the centralizing power of colonialism. the world is not a monolithic continent, there is a multiplicity of ethnic, cultural and linguistic groups, so we cannot generalize the extent to which cultural traditions do or do not have progressive norms and principles which can inform our approaches to building peace and social harmony.

We do have to be careful not to romanticise indigenous approaches to resolving disputes in particular. This is because as with the rest of humanity world countries indigenous structures were for the most part exclusionary on the basis of gender. On Jannie Malan, The majority of indigenous women were not included in the primary structures of decision making. This is why we need to combine present notions of gender equality with progressive indigenous norms and principles to 
create something that is the unique world (Malan, 1997). We have to create a framework that is a hybrid between indigenous world countries traditions and modern principles to ensure the human dignity and inclusion of all members of society women, men, girls, and boys.

Having said this, we cannot ignore the role that culture can play in enabling people to resolve their disputes and to strengthen the ties that bind them together. People derive their sense of meaning from their culture. What does it mean to be human? What is or ought to be the nature of human relations? These notions feed into the attitudes and values that we choose to embrace, which in turn determine how we interact with each other. Cultural attitudes and values, therefore, provide the foundation for the social norms by which people live (Malan, 1997). Through internalizing and sharing these cultural attitudes and values with their fellow community members, and by handing them down to future generations, societies can do reconstruct themselves on the basis of a particular cultural image.

In order to re-establish social harmony in war-affected communities, a key step would be to find a way for members of these communities to 're-inform' themselves with a cultural logic that emphasizes sharing and equitable resource distribution. This, in effect, means emphasizing the importance of reviving progressive cultural attitudes and values that can foster a climate within which peace can flourish.

\section{Banyumasan}

Literally, Banyumas was derived from 'Banyu' and 'Mas'. It means water and gold. In many cultures, water and gold are kind of mine and they have high value. According to the myth cited by Supriyadi that Banyumas mean water has value look like gold. Banyumas has a river that its clean and pure water flow from the mountain and across this area (Priyadi, 2001).

The geneology of Banyumas can be rooted in Babad Banyumas (Wijono, Soegeng, 2006). There are resources used in this Babad Banyumas. Wiyono's essay and Sunardi entitle, "Banjoemas Riwajatmoe Doeloe, Indonesia Antara Purbalingga Banyumas", Banyumas: Bawor dan Bima", "Pandangan Orang Luar terhadap Banyumas". These essays have been founded in the magazine bundle in Radar Banyumas 1999-2001.

The geneology of Banyumas can be rooted in any kinds of literature, that start by a young, Raden Baribin. He is King Prabu Brawijaya's brother. He has a habit to do spiritual act (fasting and journey to many places in Java). from this activities, King alleged him to annex his position as a King. ${ }^{4}$ Because of his fear of losing his power, Prabu Brawijaya kicked out and withdraw his throne and Prabu Brawijaya makes the duty to troops to find and kill him (Wijono, Soegeng, 2006).

In his fleeing, Baribin went to the west and with the loyal followers, they pursued to filed of fresh cucumber. While they joyed in their resting in this field, they heard disturb noise, so Baribin and his followers entered the jungle. Suddenly there was horn in here, and the troops decided that Baribin and his followers were not here. Then they left from this jungle, so Baribin and his followers safe from killing by Majapahit's troops.

From this experiences, Raden Baribin gave massage to his followers (anak putu), 1) don't plant and eat cucumber, 2) don't kill jungle horn. It's pantangan (not allowed to do) by Banyumas for respecting to founding father. So far from Majapahit, he went to the west. He heard about his killing and execution for someone who gave help to him in the west. Prabu Siliwangi from Siliwangi empire respected to Baribin and accepted and protected him. Even, Baribin got married to Siliwangi's daughter. Baribin has a son from herself, R. Ketuhu (Wijono, Soegeng, 2006).

R. Ketuhu became the founding father of Banyumas. He's from two big power, Majapahit and Pajajaran. Like his father, Ketuhu like traveling around of Java. He arrived in Wirasaba (under the power of Majapahit). He met Adipati Wirautama and he found a job in this place. So sometimes, Adipati Wirautama acknowledged him and finally, he respects and love him. Even, Ketuhu has been adopted to be lawson. Then Ketuhu became Adipati as a successor of Wirautama, next, he was

\footnotetext{
${ }^{4}$ Another version as mentioned by Priyadi that, R. Baribin as predicted by ascetics would become rulers and occupy the throne of Majapahit. See, Priyadi, "Budaya Pantangan", in Redaktur Khusus Radar, dated January 7, 2001. Interview with Suparno alias Klewer (artist) Banyumas, at his home, Jl. Brig. Encung on June 62017 hours 19.45-21.05.
} 
labeled by Wirautama II. Next era, the leader of the region is Wirautama III, Adipati Surawin, Adipati Surautama, Adipati Wargautama in this period, Wirasaba under Pajang Empire.

Banyumas is located in foot of Slamet mountain and at the bank of Serayu river. The river across this area. Banyumas decided as a "Karisedanan" at December 13, 1830 by Governor General Van Den Bosch. The this area was leaded by Hallewijn. This karisedenan consist of fives regions, Banyumas, Purbalinga, Purwakerto Cilacap, Majenang, and Banjarnegara. It's different from dealing now (Wijono, Soegeng, 2006). Because Purwakerto and Majenang include in this decision (Wijono, Soegeng, 2006).

According to Priyadi cited Wiyono and Sunardi (Wijono, Soegeng, 2006) that Adipati Djoko Kaiman is founder of Kadipaten Banyumas (1571). ${ }^{5}$ It can be entered from four directions, Purwokerta, Banjarnegara, Kebumen, and Patiraja.

Banyumas City can be entered from four directions, namely from the north from Purwokerto, from the east from Banjarnegara, south from Kebumen and Gombong, from the west from Kebasen/Patikraja as a side entrance. Serayu River is the boundary of the northern city (Wijono, Soegeng, 2006). Banyumas region has 27 districts and 331 village.

\section{Cablaka and Bawor as Identity of Banyumasan}

If you come to Banyumas territory, you feel the uniqueness dialect. We call ngapak. Ngapak is the way 'yooo' talk with ak as a suffix. For example "mangga" become "manggak" in their tongue. We find ak in the final of his articulation.

There was uniqueness term, is was called by "cablaka". Literally, "cablaka" is honesty, sincere and like look you looked. Banyumas inhabitants have a tradition of talk with "cabalaka" (Tohari, 2007).

In Banyumas, cablaka is talked directly (langsung apa anane, ora basa-basi, blak-blakan). This culture is derived from socio-cultural Banyumas as a periphery area in Java, far from the center of power (empire) in Java. Mostly, empire and power center is located in Surakarta and Jogjakarta, so Banyumas inhabitant feels free from the form built by the empire of Jogjakarta and Surakarta. So, they made their cultural and civilization including tradition in the talk, art and any variants else.

In the relation, Banyumas inhabitants call I (him/her self) with Inyong and call the opposite of speaker or you with "rika". There is no strata in the language. If we compere with Javanese language, we know I as aku, kula, kawula. It's level in language showed the status in social reality.

"Angger ngungkapna apa baen termasuk kritik, masyarakat Banyumasan kuwe umume diungkapna langsung, terbuka ning carane sing ora marekna kesuh wong sing dekritik, terus umume diungkapna nganggo nada humor malah ngarah sing seronok dadi tetep bisa njaga suasana adem". 6

Banyumas language is equal and egalitarian. It's the core of Banyumas language. It has equality at the font of humanity. This point of view inequality appears cablaka showed in social relation. According to Priyadi (Priyadi, 2001), equity ethic in humanity not only appears the power of solidarity in Banyumas inhabitants but also build behavior of penjorangan ${ }^{7}$, semblothongan, ${ }^{8}$ glewehan ${ }^{9}$ much more. In Banyumasan tend to be friendly.

\section{India}

\footnotetext{
${ }^{5}$ Interview with Rahmat Basuki on March 15, 2006.

${ }^{6}$ When expressing anything, including points, is conveyed directly and openly, but in a way so that people who are criticized are not angry and generally delivered with humor that sometimes leads to seronok, so this can be an atmosphere of being cool. See, http://map-bms.wikipedia.org/wiki/Cablaka/Blakasuta.

${ }^{7}$ Penjorangan means to joke that sometimes leads to impudence.

${ }^{8}$ Semblothongan berarti canda atau kelakar yang tidak sopan.

${ }^{9}$ Glewehan means joke.
} 
Dravida $^{10}$ and Aria is originally majority tribe in old India. Mostly Dravida is animism and dynamism. Aria tribe worship the sun, fire, moon, space and sea, trees, rivers, and idols. For worship to their god, they usually slaughter men an animals. Aria more dominant than Dravida. Aria enforces to Dravida to follow Aria in the belief, they became Sudra level. In 559 B.C was born Mahawir to be a pioneer of Jaina religion. The type of this religion is leaving any luxuries. They haven't holy scripture. One of the sources in this religions is Mahawir. The core of Jaina is "ahimsha" (not envy). This principle is suitable for all, then these principles unite to Hinduism (Christian Mabel Duff Rickmers, 1899). The Gautama born as a protester in Hindu. He is the pioneer in Budha, the principles of Budha is there is no the level status (kasta), no envy, the and must be tolerant, charity, good thinking, patient, and good the in the job, and all of we have we give to God (Ali, 1980).

We knew about the politic situation in old India. Subcontinent India consists of any authorities under little dynasties. Any dynasties quarrel each other. In the seventh century, because of quarrel Islam can enter to India easily. In India tradition, the king is a leader and mostly he is a dictator. He merged any authorities, legislative, judicial, and executive and army. Empire was consisted of the province, and was led by "Uparika". The Uparika duties were the keeper of the area, organizer of the area, actor to do king's instruction. Province was consisted of the district (Vaisaya) and was leaded by Panchayat.

Islam entered to India by informal. Firstly, Islam merchants entered to India with their properties. In this prophet era, any Indians (tribes Jat) lived in Arab as a traditional medicine (tabib), one of them heal Rasulullah's wife, Aisyah and he become assistant of Aisyah. And we know one of the wife of Rasullullah was from India, and Rasullah ever siad, "May Allah bless this Hind and the country after which she is named"

We knew about the message about Hind from Prophet Muhammad about two groups who save from hell. They were conquered to India and one of them is troops follow to Isa son of Maryam (Muhammad Reza I Karim, 1972).

In Umar Ibn Khtattab period, Islam entered to Persia, and on the hand of Abdullah bin Amar, Islam entered Kirman, Siszistan, and Mekran (R. E. M. Wheller, 1950). The next caliph Ustman ibn Affan, he sent Hakim al-Jabalah to entered India. And then was succeeded by Umayya dynasty (M. Abdul Karim, 2001). From this moment, India became one destination to be market and for politic struggling domains. Dynasty of Ghazni ever been taken authority in India. Mahmud threth teen times entered India and conquest any place in India. Mostly north of India can be sit down. If we analyze the result of Mahmud, little of the area to be permanent, except Punjab. The effect of Mahmud invasion can be felt until now politically, cultural, economic, and knowledge.

Sultan Mahmud is one of the greatest personalities in Indian history. The Indian campaign carved a gold ink record in its accomplishment as a soldier and general. According to Stanley Lanepoople, "Mahmud is a soldier based on a man who has the endless courage and endless energy, mind, and growth. He repeatedly (seventeen times) led an expedition to India but none of his defeats. He had to face the combined forces of Indian kings and in the event, he defeated them all. Mahmud was a very careful and fearless military general. According to S.M. Jaffar, "Mahmud is endowed with the intelligence of war. He is a scientific general, an expert in planning, and a total in execution. "He will make the best preparation and plan before any invasion. For 32 years in power, he conquered many places and expanded his work covering all areas now known as Afghanistan, the largest part of Peria, Transoxiana, and Punjab.

It was not a small feat to develop the small kingdom of Ghazni mountains into a large and prosperous kingdom with little armed forces. He was born a strong leader and conqueror. He never retreats from war; even he likes to fight. His army consists of heterogeneous elements such as Arabic, Afghan, Turkish, Khalji, Ghaznawi and Indian but he demonstrates a remarkable ability to unite these elements into a powerful and invincible unity. As a conqueror, his goal is to achieve fame and glory and he has attained it. There are three ways to enter Islam informally through trade, the role of Sufis and clerics, and marriage.

First step, Trade Long before the Greeks knew India (V-IV BC), Arabs already had an Indian relationship. Merchants bring products from Central Asia, Africa, even from Europe, and exchange them with these Eastern commodities. Through trade, Arab-Indian relations became harmonious. [Imam Ibn Qayyim al-Jauziah, Zad al-Maad fi Hadyi Khair al-Thad Muhammad Khatim alNabiyyin wa Imam al Mursali, volume III (Cairo: Mathba'ah al-Mesriyah , 1379 H), p. 63-99] When

${ }^{10}$ Before the Dravidas, there were already Negroid and Austroloid peoples who kept Indian territory, but their history was not widely known. 
Islam was born in Mecca brought by the Prophet Muhammad. In the year $610 \mathrm{AD}$, the Arab traders have embraced Islam So that while they trade also berda'wah.

Strong evidence of a trade relationship between Arabia and India is the discovery of currency coins at the time of Caliph Harun al-Rashid print in 788 AD in Mainamati and Paharpur in East India. The Arabs came to India to trade and spread Islam. Moreover during the dynasty of the ghuri rule of Delhi, more and more Muslim traders came to Indian lands while preaching Islam. Minhaj al-Siraj explained that long before Ikhtiyaruddin Bakhtiyar Khalji had crushed Nadia, many of the horse merchants who came there were from Arabia, Persia and northern India.

Second way, Sufi and Mubaligh, from the very first time Islam entered, the teachings of Islam were undertaken by scholars, Sufis, guardians, and Islamic forces from Arabia, Yemen, Persia, Turkey, Afghanistan and Central Asia. The influence of Islamic teachings is very great on the life of the people. The role of the 'Wali Allah' and 'Sufis' in broadcasting the religion of Islam on the land of India is very large indicated by the large number of those who come to India. They were among the first to spread Islam before Islam entered India formally. When the Islamic government came to power in India their role did not diminish and even increase the religion of Islam in the country. The famous Sufi in the army of Abu Yazid Bustami (d. 872 AD). he studied with the Sinds for a few years, then moved to East India (Chittagong). There is a long stay and is known by the name Bayazid Bustami. When it comes to the region that Islam already exists, but not many. He founded Khankah (Islamic religious broadcasting center, a kind of boarding school). His efforts contributed greatly to the development of Islam there. Many people around him who study religion and convert to Islam. Upon hearing the news that his mother was ill, is back to Bustam. Although until the end of his life is not kmbali to India, but there was found a grave in his name. Every day thousands of people there come to the 'graveyard'.

Third way, Marriage, in addition to the activities of conquest, trade, and da'wah of the Sufis, Islam also spread through marriage. For example the events of the Arab merchant ship that hit Ramri Island, so they settled in Arakan and Chittagong. These merchants mix with indigenous peoples and many marry indigenous girls.

Historians say that Muslims who come to India, in addition to bringing Islam, also have the medical science prowess that they get from the claim of the hadith of the Prophet Muhammad. Concerning drugs, as described in Zad al-Ma'ad's book the composition of Ibn al-Qayyim. The Prophet is a representative of God, the Caliph is the successor of the Prophet, and the Sultan is the representative of the Caliph. This was after the Abbasid Caliphate in Baghdad was destroyed by Hulagu Khan in $1258 \mathrm{AD}$ and to the Caliphate was transferred to Egypt by the Sultan of Baybars of the Mamluk dynasty (1261 AD) who used the Khalifah's office for his political interests. Sultan Salim of Ottoman Turks ruled Egypt (1517 AD) and the last Abbasid Caliph in Egypt was taken to Istanbul to re-establish the Caliphate. So since then the Turkish ruler as the sultan for his territory and the Caliph for the whole Islamic world. Of this activity many Indians are attracted to Islam and many are finally established marital relationships between patients or their families with Muslims who have helped to cure the disease.

The great majority of Indians who convert to Islam come from Buddhist circles and lower-class Hindus who for simplicity, equality, and brotherhood in religion, and the Islamic social system are attractive as saviors of suffering and tyranny by Brahmins. Nevertheless, not a few Hindus from the upper classes who converted to Islam mainly through marriage with Muslims. This is evidenced from the following quote: "There are examples which show that Islam gained a considerable number of converts through marriage in upper class Hindu families."

\section{Religious Local Wisdom in New Delhi}

According Girlis, in India, especially in New Delhi, Hinduism is not religion. Hinduism is dharma. Dharma is ethics. In Hinduism, we have any ethics or dharma. Ethics for eat, sleep, work, and relation. Any activities have ruled by dharma. The followers of Hinduism must obey the rules, including about relation. Dharma Samanvaya is one kind of relation ethic. All of creature must adhere principles and obey rules. Issue of terrorism in several religion can be reduced by spreading understand about it. ${ }^{11}$

${ }^{11}$ Interview with Prof. Girlis, December 7, 2017. 
According Maulana Wahiduddin Khan, that telationship between Moslem and Non Moslem in India is in good condition. Islam encourage to its followers (moslem) to adhere the Islamic principles that were conveyed by Allah. Islam is "salam", peace. Any verses since al-Fatihah to al-Nas encourage to be peace community.

Terrorism that has labelled in Moslem community is politic issue. According to Maulana, we must learn with nature, "Nature is not simply a wonderful world. It is rather than an amazing garden for spirituality". What relation between spirituality and harmony ?, Spirituality consist of mental quality. Inner quality spread to external actualization. If we can discover the value of well-wishing, and decide to live as a well-wisher for all mankind we have applied spirituality for social harmony.

In this statement, "The power of positive behaviour can triumph over the power of negativity, while the power of negativity cannot win anything -it only leads to destruction". Terrorism loses by annoying. We don't support terrorism with reposting statement and picture from terrorists. Sufism is an Islamic spiritualism. By Sufism, Moslem can explore high capacity or spiritual quality by the emptying process (takhalli), fulfilling process (tahalli), and actualizing process (tajalli). ${ }^{12}$

According to Swami Shantatmanand Hinduism is not only religion but also dharma. Darma is ethics. Ramakrishna mission has an ideology about social harmony. It's called by Dharma Siwan Waya. Ramakrishna mission is an organization that promotes Swami Ramakrishna's idea. One urgent ide about relationship majority and the minority is, "Not only toleration, I believe in acceptance". Not only tolerance, for so-called tolerance is often blasphemy, and I do not believe in it. I believe in acceptance. Why should I tolerance? Tolerance means that I think you are wrong and I am just allowing you to live. It is not blasphemy to think that you and I are allowing other to live ?"

Harmony is different from tolerance. Harmony of religions should be distinguished from religious tolerance. Toleration implies a certain degree of condescensions and retaining from doing something worse.

Ramakrishna Misson has a universal ideology. It is different from exclusivism, inclusivism, and pluralism. Exclusivism is the view that one's own religion alone is true and all the other religions are false. When exclusivism finds aggressive social expression, it becomes fundamentalism. The rise of fundamentalism in several religions and the adaptation of extremist and terrorist tactics by some fundamentalists groups, constitute the main threat to global peace, friendship, and prosperity in the present day world. ${ }^{13}$

Inclusivism holds that one's own religion alone is true, but is does not hold that other religion are false, for they are all included in one's own religion. Pluralism holds that all world religions are true. Revelation is many, and there are several paths to salvation/liberation.

Universalism is the view that the exists a set of universally valid religious principles common to or unifying all religions. Universalism emphasizes the common ground among religions.

"Religions of the world are not contradictory or antagonistic. They are but various phases of one Eternal Religion. That one Eternal Religion is applied to a different planet of existence, is applied to the opinions of various minds and various races. There never was religious is your, one infinite Religion existed all through eternity and will ever exist.

Expressing itself in various countries in various ways (Swami Vivekananda). Swami Shantatmanand said that Dharma Samanvaya is religious local wisdom in Hindu. It is the principle of tolerance to all religions. It was one of Gandhi's commandments and is one of Hinduism's foundations since immemorial times. This principle referred to Veda, As stated in the RigVeda: "Ekam Sat Vipra Bahudha Vadanti-that which exists is One: sages call it by various names". And in Bhagavad Gita: "E no Bhagavad Gita", "Howsoever men approach Me, even so, do I welcome them, for the path men take from every side is Mine". All of the religions must respect others. Swami said that there is no problem if Moslem call for praying, in their masjid even in the daybreak. I feel good and it is no problem for me. ${ }^{14}$

According to Mr. Dr. Gautam, India is very unique like Indonesia. One kind of uniqueness of India is "harmony life in diversity", He said that India has several religions and faiths. We can say, India has Hinduism (as a majority), Christianity, Islam, Sikh, and others. Generally, India can manage this diversity as a positive energy.

Hinduism as a majority in India respect to a minority like Islam and other religion. But sometimes there were any tensions. It's natural. He mentioned the relation between majority and

\footnotetext{
${ }^{12}$ Interview with Maulana Wahiduddin Khan, December 4, 2017.

${ }^{13}$ Interview with Swami, December 5, 2017.

${ }^{14}$ Interview with Swami, December 5, 2017.
} 
minority in India, especially about inter-dependency. Moslem society in the rural of India has much contribution to make a thick blanket from wool. They were called by "Dunya". Dunya is a social group or "kasta" in India who has expertness or masterliness in blanket production made by handcraft. There isn't Hinduism society who cannot handle it. So, Mr. Gautam gave a statement that relation majority and the minority can be well groomed by inter-dependency. ${ }^{15}$

According to Aslam Islahi, Islam respect for others. It refers to al-Qur'an that Allah gave a message about human dignity (wa laqad karramna bani Adam). Indeed, we (Allah) has given honor or dignity to humanity. Aslam said that Islam drives to harmony, including social and even ecological harmony. It is referred to al-Qur'an in any verses. Allah said in al-Quran, we don't send exact to "rahmatan lil alamin", as a grace for the world. It isn't only for a human being, but also to plants, animals, and particles.

Aslam said that Islam drives to harmony, including social and even ecological harmony. It is referred to al-Qur'an in any verses. Allah said in al-Qur'an, we don't send exact to "rahmatan lil alamin", as a grace for the world. It isn't only for human being, but also to plants, animals, and particles.

Islam teaches the mercy for all to Moslem in Hajj. In Hajj, Moslem must wear the ihram and they are prohibited to destroy (fusuq), debate (jidal), and talk and act porn (rafats). Islam tends to make social harmony. Several cases may occur in India conducting relationship between majority and minority is very natural. If there is, usually it was triggered by situations and it's usually there is high tension in election session.

There's a politicization of cases conduction social harmony. Originally, there is no problem about relation about Islam and non-Moslem in India. Islam and non-Moslem in India live together.

Religious local wisdom in Moslem society based on Qur'an Hadits like "Karramna bani Adam", and Ihram. From this concept, Moslem must spread peace and harmony in the world. Issu about terrorism is politic domain. Moslem must reject is a label by implementing peace life in our society. Terrorism shows violence, Islam rejects it. If Moslem understand and implement shalat in every day, God will, Moslem be good Moslem. Their life is peace to others. ${ }^{16}$

\section{Conclusion}

Any characteristics religious local wisdom that effective to build social harmony. First, it that improve to make more social interdependent. Second, It produces to make more and deep understand about life. Cablaka in Banyumas and Darma Samanvaya in New Delhi have two characteristics.

\section{References}

[1] Alfitri, \& Hambali. Integration of national character education and social conflict resolution through traditional culture: A case study in South Sumatra Indonesia. Asian Social Science, 9 (12 SPL ISSUE), 125-135. https://doi.org/10.5539/ass.v 9 n 12 p125 (2013).

[2] Ali, K. History of India, Pakistan, and Bangladest. Dhaka: Ali Publication (1980).

[3] Boris, \& Samuel. (2014). Statistics and political violence: Reflections on the Social Conflict in in Guadeloupe. Partecipazione E Conflitto, 7 (2), 237-257 (2009) https://doi.org/10.1285/I20356609V7I2P237.

[4] Christian Mabel Duff Rickmers. The Chronology of India, from the Earliest Times to the Beginning Os the Sixteenth Century. Whitehall Gardens: Archibald Constable \& Co (1899).

[5] Fallis, A. Christian-Muslim Relation in Ghana: A Model for World Dialogue and Peace. Journal of Chemical Information and Modeling, 53 (9), 1689-1699 (2013). https://doi.org/10.1017/CBO9781107415324.004.

[6] Graybill, L. S. South Africa's Truth and Reconciliation Commission: Ethical and Theological Perspectives. Ethics \& International Affairs, 12, 43-62 (1998). https://doi.org/10.1111/j.17477093.1998.tb00037.x.

[7] Lopera Becerra, A. F. The Social Conflict, a Necessary concept in the Education for Peace. Ra Ximhai, 10(Iss Especial 4) (2012).

\footnotetext{
${ }^{15}$ Interview with Gautam K. Jha, December 4, 2017.

${ }^{16}$ Interview with Aslam Islahi, December 4, 2017.
} 
[8] M. Abdul Karim. Kontribusi Muhammad ibn Qasim dalam Penaklukan Sind. THAQAFIYYAT: Jurnal Bahasa, Peradaban Dan Informasi Islam, 2 (2) (2001).

[9] Malan, J. Conflict Resolution Wisdom From Africa (1997).

[10] Muhammad Reza I Karim. Arab Jatir Itihas : History of the Arabs. Dhaka: Bangkla Academy (1972).

[11] Parry, W. T. THE UNITY OF OPPOSITES : A DIALECTICAL PRINCIPLE. 12(4), 418-444 (2014).

[12] Priyadi, S. Budaya Pantangan. Redaktur Khusus Radar (2001).

[13] R. E. M. Wheller. Five Thousands Years of Pakistan. London: Cristopher Jhonson (1950).

[14] Reychler, Luc., Paffenholz, T. Peacebuilding: A Field Guide. Boulder, Colo.: Lynne Rienner Publishers : In association with the Field Diplomacy Initiative (2001).

[15] Roqib, M. Harmoni dalam budaya Jawa: dimensi edukasi dan keadilan gender. Yogyakarta: Pustaka Pelajar (2005).

[16] Sefton-Green, R. Multiculturalism, Europhilia and harmonization: harmony or disharmony? Utrecht Law Review, 6(3), 50 (2010). https://doi.org/10.18352/ulr.140.

[17] Spiegel, P. B., \& Nankoe, A. UNHCR , HIV / AIDS and refugees : lessons learned. 21-23 (2002).

[18] Sundquist, J., Hagströmer, M., Johansson, S.-E., \& Sundquist, K. Effect of a primary health-carebased controlled trial for cardiorespiratory fitness in refugee women. BMC Family Practice, 11 (1) 55 (2010).. https://doi.org/10.1186/1471-2296-11-55.

[19] Tcach, C. Cordoba: Left Workers and Social Conflict in the Government of Amadeo Sabattini. Sociohistórica. Cuadernos Del CISH, 19-34. Retrieved from (2012).https://dialnet.unirioja.es/servlet/articulo?codigo $=4357359$.

[20] Tim Murithi, D. P. African Principles of Conflict Resolution and Reconciliation. Addis Ababa: Shebelle Publishing (1999).

[21] Tohari. Kamus Bahasa Banyumas. Banyumas: Yayasan Swarahati Banyumas (2007).

[22] Wijono, Soegeng, S. Banjoemas : Riwajatmoe Doeloe. Wonosobo: Daya Mandiri Production (2006). 